\title{
CD248 Gene
}

National Cancer Institute

\section{Source}

National Cancer Institute. CD248 Gene. NCI Thesaurus. Code C78157.

This gene may play a role in angiogenesis. 